\title{
WATER LEVELS IN WELLS J-11 AND J-12, 1989-91, YUCCA MOUNTAIN AREA, NEVADA
}

\author{
by Michelle S. Boucher
}

\section{U.S. GEOLOGICAL SURVEY}

Open-File Report 94-303

Prepared in cooperation with the

U.S. DEPARTMENT OF ENERGY under

Interagency Agreement DE-Al08-92NV10874

\section{DISCLAIMER}

This report was prepared as an account of work sponsored by an agency of the United States Government. Neither the United States Government nor any agency thereof, nor any of their employees, makes any warranty, express or implied, or assumes any legal liability or responsibility for the accuracy, completeness, or usefulness of any information, apparatus, product, or process disclosed, or represents that its use would not infringe privately owned rights. Reference herein to any specific commercial product, process, or service by trade name, trademark, manufacturer, or otherwise does not necessarily constitute or imply its endorsement, recommendation, or favoring by the United States Government or any agency thereof. The views and opinions of authors expressed herein do not necessarily state or reflect those of the United States Government or any agency thereof.

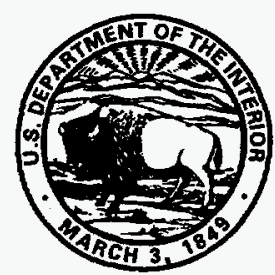




\section{U.S. DEPARTMENT OF THE INTERIOR BRUCE BABBITT, Secretary \\ U.S. GEOLOGICAL SURVEY \\ Gordon P. Eaton, Director}

The use of trade, product, industry, or firm names is for descriptive purposes only and does not imply endorsement by the U.S. Government.

For additional information write to:

Chief, Hydrologic Investigations Program

Yucca Mountain Project Branch

U.S. Geological Survey

Box 25046, MS 421

Denver Federal Center

Denver, CO 80225
Copies of this report can be purchased from:

U.S. Geological Survey

Earth Science Information Center

Open-File Reports Section

Box 25286, MS 517

Denver Federal Center

Denver, CO 80225 


\section{DISCLAIMER}

Portions of this document may be illegible in electronic image products. Images are produced from the best available original document. 


\section{CONTENTS}

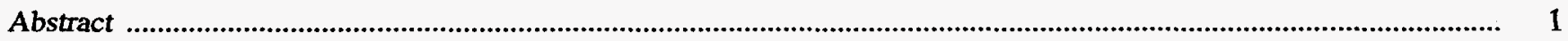

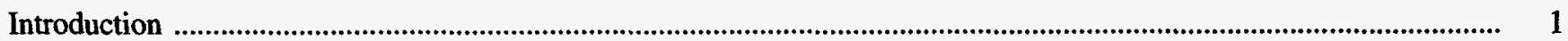

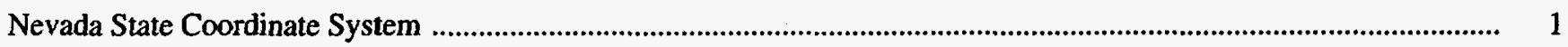

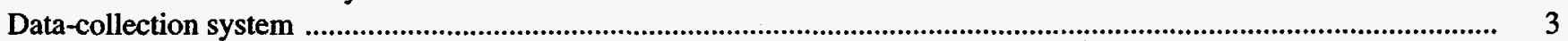

Corrections and adjustments to manual measurements ..............................................................................

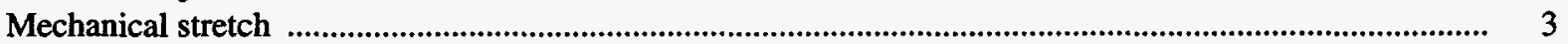

Thermal expansion ............................................................................................................................................... 3

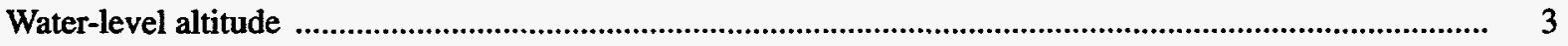

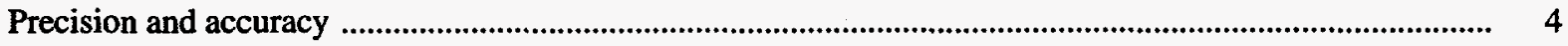

Quality assurance ......................................................................................................................................................... 4

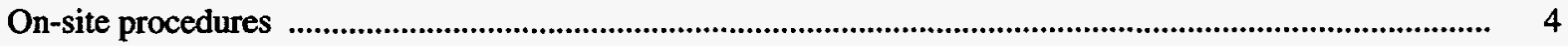

Office processing and review ................................................................................................................... 5

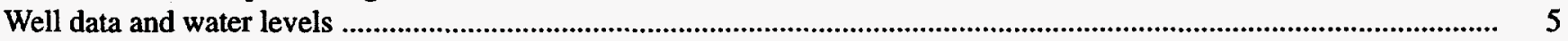

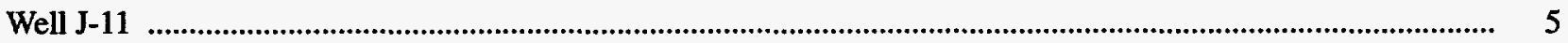

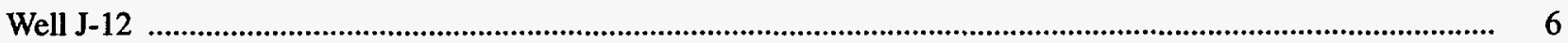

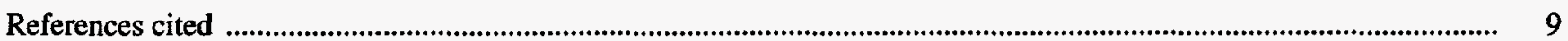

\section{FIGURES}

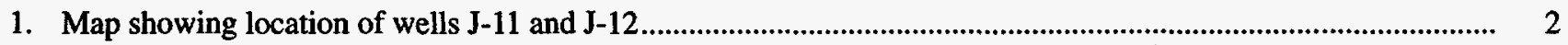

2. Hydrograph showing water-level altitude, 1989-91, for well J-11 near Yucca Mountain, Nevada ............................. 7

3. Hydrograph showing water-level altitude, 1989-91, for well J-12 near Yucca Mountain, Nevada ......................... 8

\section{TABLES}

1. Corrections applicable to steel tapes used for measuring water levels, 1989-91, at wells J-11 and J-12, near Yucca Mountain, Nevada ................................................................................................................................ 4

2. Mechanical-stretch and thermal-expansion equation variable values for steel tapes used in the vicinity of Yucca Mountain

3. Measured water-level altitude and yearly mean water-level altitudes, 1989-91, for well J-11 near Yucca Mountain, Nevada

4. Measured water-level altitude and yearly mean water-level altitudes, 1989-91, for well J-12 near Yucca Mountain, Nevada

\section{CONVERSION FACTORS AND VERTICAL DATUM}

\begin{tabular}{rll}
\hline Multiply & By & To obtain \\
\hline kilometer $(\mathrm{km})$ & & mile \\
liter $(\mathbf{l})$ & 0.6214 & cubic foot \\
$\operatorname{meter}(\mathrm{m})$ & 0.03531 & foot \\
inch
\end{tabular}

Degree Celsius $\left({ }^{\circ} \mathrm{C}\right)$ may be converted to degree Fahrenheit $\left({ }^{\circ} \mathrm{F}\right)$ by using the following equation:

$$
{ }^{\circ} \mathrm{F}=9 / 5\left({ }^{\circ} \mathrm{C}\right)+32 \text {. }
$$

Sea level: In this report "sea level" refers to the National Geodetic Vertical Datum of 1929 (NGVD of 1929)-a geodetic datum derived from a general adjustment of the first-order level nets of both the United States and Canada, formerly called Sea Level Datum of 1929. 


\title{
Water Levels in Wells $\mathrm{J}-11$ and $\mathrm{J}-12,1989-91$, Yucca Mountain Area, Nevada
}

\author{
By Michelle S. Boucher
}

\begin{abstract}
Water levels have been measured in the Yucca Mountain area, Nevada, since 1981 in order to gain a better understanding of the ground-water flow system in the area. Water levels in wells J-11 and J-12 have been periodically measured using calibrated reeled steel tapes since 1989, however, calculation of waterlevel altitude was not possible prior to 1993 due to missing reference elevations. These elevations were determined in 1993 by the U.S. Geological Survey. During 1989-91, water-level altitudes for well J-11 ranged from 732.09 to 732.40 meters and the mean water-level altitude was 732.19 meters. During 1989-91, water-level altitudes for well J-12 ranged from 727.84 to 728.03 meters, and the mean waterlevel altitude was 727.95 meters.
\end{abstract}

\section{INTRODUCTION}

The Yucca Mountain area is being evaluated by the U.S. Department of Energy for suitability to store high-level nuclear waste in a mined, underground repository. A $150 \mathrm{~km}^{2}$ area located about $150 \mathrm{~km}$ northwest of Las Vegas in southern Nevada is being studied extensively (fig. 1). Water levels in selected wells have been measured periodically since 1981 to gain a better understanding of the ground-water flow system in the area. Water-level altitude data will be used to determine the direction and rate of groundwater flow, and also will be used to estimate hydraulic characteristics of the flow system. In the Yucca Mountain area, the water table is in air-fall and ash-flow tuffs of Tertiary age. Saturated carbonate rocks of Paleozoic age underlie the Tertiary volcanic rocks. The terminology for stratigraphic units in this report follows Carr (1988), Carr and others (1986), Byers and others (1976), and Winograd and Thordarson (1975).

Water levels in two water-supply wells, J-11 and J-12 (fig. 1), near Yucca Mountain have been periodically measured using calibrated steel tapes since 1989; however, water-level altitudes above sea level have not previously been reported because the altitudes of the measuring points (MP) were not known. Measuring- point altitude data are needed in order to calculate the altitude of the water table above sea level.

This report presents water-level altitudes for wells $\mathrm{J}-11$ and $\mathrm{J}-12$ during 1989-91, describes the equipment and methods used to collect and calculate water-level altitudes, and presents descriptions of the wells.

This report is a companion and supplement to reports about periodically measured water levels (Robison and others, 1988; Gemmell, 1990; O'Brien, 1991) in the Yucca Mountain area. These companion reports present water-level data for 11 additional wells that are monitored periodically. Robison and others (1988) described the details of how the manual waterlevel measurements are made and corrected to compute the altitude of the water level.

Water-level data were obtained as part of the Yucca Mountain Project of the U.S. Department of Energy. The Yucca Mountain Project is described by a Site Characterization Plan (U.S. Department of Energy, 1988). The data in this study were collected by the U.S. Geological Survey and its contractors in cooperation with the U.S. Department of Energy under Interagency Agreement DE-AI08-92NV10874.

\section{NEVADA STATE COORDINATE SYSTEM}

Nevada State Coordinates are used to identify the location of the wells cited in this report. These coordinates are for the central zone of Nevada and are based on a Transverse Mercator Projection. The origin of this projection for the central zone of Nevada is latitude $34^{\circ} 45^{\prime} \mathrm{N}$., and the central meridian is longitude $116^{\circ} 40^{\prime} \mathrm{W}$. The Nevada State Coordinates listed in the "Well Data and Water Levels" section are in meters north of the origin and in meters plus 152,400 east of the central meridian. The Nevada State Coordinates for the wells were determined by Holmes and Narver, Inc., contractor to the U.S. Department of Energy for surveying at the Nevada Test Site and Yucca Mountain area. Latitude and longitude values of the wells were calculated from the Nevada State Coordinates. 


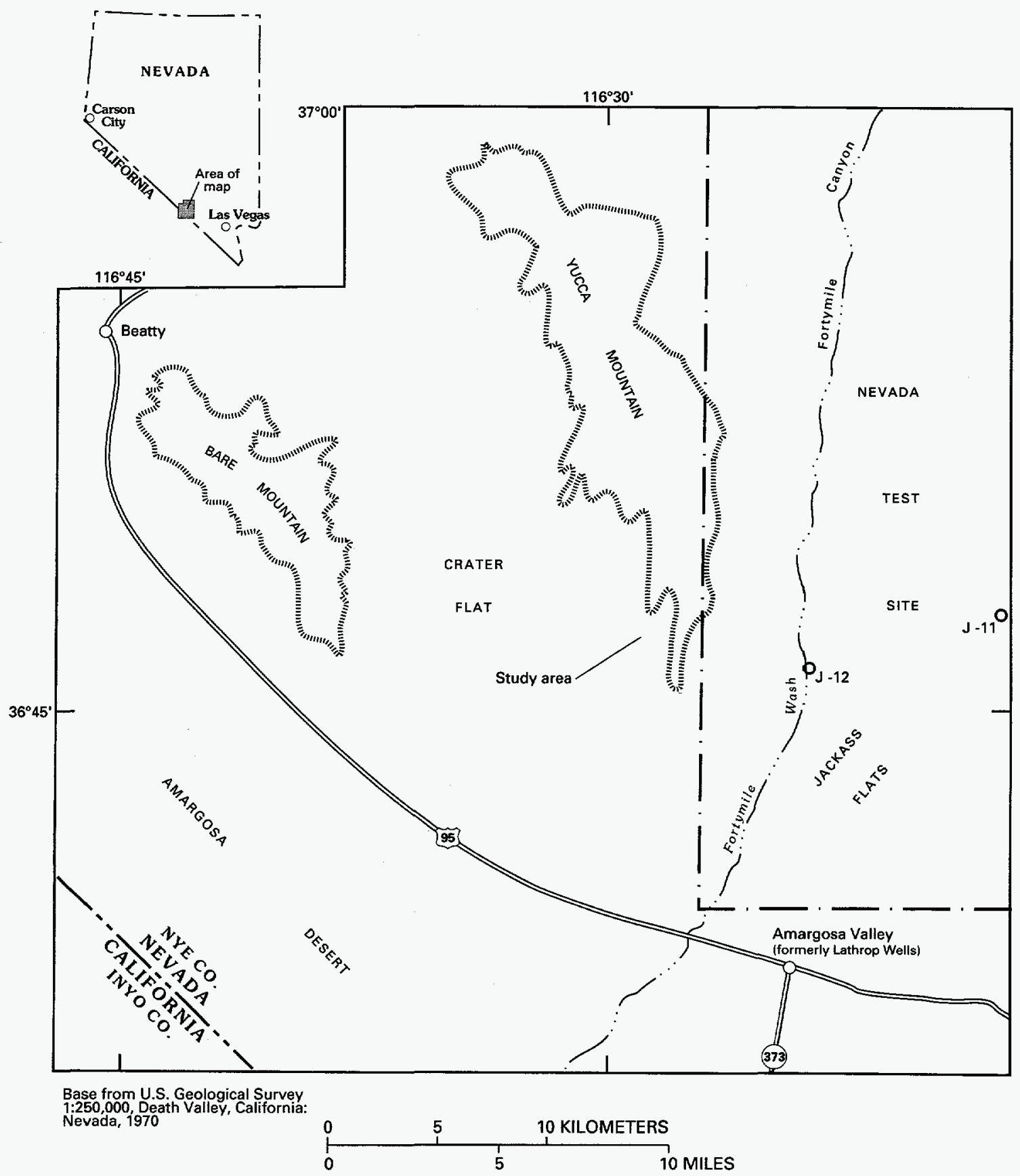

Figure 1. Location of wells $\mathrm{J}-11$ and $\mathrm{J}-12$. 


\section{DATA-COLLECTION SYSTEM}

Periodic water-level data are collected at Yucca Mountain by means of manual measurements made using reeled steel tapes or multiconductor cable units. Periodic measurements during 1989-91 were made using two specially constructed reeled steel tapes that are $7.9 \mathrm{~mm}$ wide and $792 \mathrm{~m}$ long, designated as Chain \#1 and Chain \#2. Also used was a 2,800-ft reference steel tape, which is a reeled steel tape $6.4 \mathrm{~mm}$ wide and $853 \mathrm{~m}$ long. Detailed descriptions of Chain \#2 and the reference steel tape are given by O'Brien (1991). Chain \#1 has the same physical characteristics as Chain \#2. Periodic measurements are subject to various corrections that are listed in the following sections.

\section{Corrections and Adjustments to Manual Measurements}

Various factors affect the accuracy of manual water-level measurements and are considered in the process of determining the water-level altitude. All measurements in this report indicate the corrected water-level altitude. Corrections made for steel-tape water-level measurements include mechanical stretch and thermal expansion of the tape. Measurements are not corrected for borehole deviation from vertical as gyroscopic surveys have never been run in wells $\mathrm{J}-11$ and J-12. Measurements are adjusted to sea level datum. The correction factors applied to steel-tape measurements for each well are summarized in table 1.

\section{Mechanical Stretch}

Mechanical stretch is associated with the weight of the steel tape and attached plumb bob. The calculated adjustment for the steel tapes used during 1989-91 (Chains \#1 and \#2), based on stretch coefficients and an approximate weight of $0.45 \mathrm{~kg}$ for the plumb bob, were $-0.02376 \mathrm{~m}$ for well $\mathrm{J}-11$ and $-0.02141 \mathrm{~m}$ for well $\mathrm{J}-12$ (table 1 ).

The correction for mechanical stretch of the tape is given by:

$$
\mathrm{C}=\left(\mathrm{L}^{2} \mathrm{WS}\right) / 2+\mathrm{PLS}-\mathrm{KLS}
$$

where

$\mathrm{C}$ is the correction, in meters;

$\mathrm{L}$ is the average depth to water in the well, in meters;

$\mathrm{W}$ is the unit weight of the tape, in kilograms per meter;
$S$ is the stretch coefficient, in meters per meter-kilogram;

$P$ is the weight of the plumb bob, in kilograms; and

$\mathrm{K}$ is reference tension during manufacture, in kilograms.

Values for the variables in equation (1) are given in table 2 for each tape. Values for $\mathrm{W}$ were determined at a calibration laboratory at the NTS, and values for S were determined by the U.S. Geological Survey and are believed to be accurate to 7 percent. Values for $\mathrm{K}$ were provided by the manufacturer at the time of purchase.

\section{Thermal Expansion}

Thermal expansion of a steel tape responds to temperature changes. The calculated correction for thermal expansion for steel tapes is based on manufacturer specifications for thermal-expansion coefficients and on average hole temperature calculated from temperature profiles in wells at Yucca Mountain (Sass and Lachenbruch, 1982). The correction factors are $+0.01842 \mathrm{~m}$ for well $\mathrm{J}-11$ and $+0.01317 \mathrm{~m}$ for well $\mathrm{J}-12$ (table 1).

Correction for thermal expansion of the tape is given by:

$$
E=(D-R) T L,
$$

where

$\mathrm{E}$ is the correction, in meters;

$\mathrm{D}$ is the assumed average air temperature in the well, in degrees Celsius;

$\mathrm{R}$ is the reference temperature during manufacture, in degrees Celsius;

$\mathrm{T}$ is the thermal expansion coefficient, in meters per meter-degree Celsius; and

$\mathrm{L}$ is the apparent length of the tape, in meters.

The tape corrections, which include mechanical stretch and thermal expansion and average air temperature in the well, are given in table 1 . The tapedependent variables for equation 2 are defined for each tape in table 2.

\section{Water-Level Altitude}

Water-level altitude is calculated by subtracting the true depth to water (after applied corrections) from the altitude of the reference point, which generally is a metal tag on the well casing. The MP for the wells, at the top of the well access tube, is at some distance above the reference point, and the height of the MP is 
Table 1. Corrections applicable to steel tapes used for measuring water levels, 1989-91, at wells J-11 and J-12, near Yucca Mountain, Nevada

\begin{tabular}{|c|c|c|c|c|c|c|c|c|c|}
\hline \multirow{2}{*}{$\begin{array}{c}\text { Well } \\
\text { number }\end{array}$} & \multirow{2}{*}{$\begin{array}{c}\text { Assumed } \\
\text { average air } \\
\text { temperature } \\
\text { in well } \\
\text { (degrees } \\
\text { Celslus) }\end{array}$} & \multicolumn{3}{|c|}{$\begin{array}{l}\text { Correction for 2,800-ft reference } \\
\text { steel tape (meters) }\end{array}$} & \multicolumn{3}{|c|}{$\begin{array}{l}\text { Correction for Chain *1 and } \\
\text { Chaln } * 2 \text { (meters) }\end{array}$} & \multirow{2}{*}{$\begin{array}{l}\text { Measur- } \\
\text { ing } \\
\text { point } \\
\text { (meters) }\end{array}$} & \multirow{2}{*}{$\begin{array}{c}\text { Altitude } \\
\text { of } \\
\text { reference } \\
\text { point } \\
\text { (meters) }\end{array}$} \\
\hline & & $\begin{array}{l}\text { Mochanical } \\
\text { stretch }\end{array}$ & $\begin{array}{c}\text { Thermal } \\
\text { expansion }\end{array}$ & Total ${ }^{1}$ & $\begin{array}{l}\text { Mechanical } \\
\text { stretch }\end{array}$ & $\begin{array}{c}\text { Thermal } \\
\text { expansion }\end{array}$ & Total' & & \\
\hline $\mathrm{J}-11$ & 25.0 & -0.04188 & 0.01842 & -0.02346 & -0.02376 & 0.01842 & -0.00534 & 0.55 & $1,049.45$ \\
\hline $\mathrm{J}-12$ & 25.0 & -0.03525 & 0.01317 & -0.02207 & -0.02141 & 0.01317 & 0.00824 & 0.53 & 954.54 \\
\hline
\end{tabular}

Total correction may not equal sum of mechanical stretch and thermal expansion due to rounding.

Table 2. Mechanical-stretch and thermal-expansion equation variable values for steel tapes used in the vicinity of Yucca Mountain

\begin{tabular}{lcc}
\hline \multicolumn{1}{c}{ Variable } & 2,800-ft reference steel tape & Chain \#1 and Chain \#2 \\
\hline Unit weight of the tape, W (kilogram/meter) & $2.08 \times 10^{-2}$ & $2.59 \times 10^{-2}$ \\
Stretch coefficient, S [meter/(meter-kilogram)] & $2.48 \times 10^{-5}$ & $1.66 \times 10^{-5}$ \\
Weight of plumb bob, P (kilogram) & 0.45 & 0.45 \\
Reference tension during manufacture, K (kilogram) & 9.07 & 9.07 \\
Reference temperature during manufacture, R (degree Celsius) & 20 & 20 \\
Thermal expansion coefficient, T [meter/(meter-degree Celsius)] & $1.16 \times 10^{-5}$ & $1.16 \times 10^{-5}$ \\
\hline
\end{tabular}

subtracted from the apparent depth to water when calculating the true depth to water. Reference-point and MP values for wells $\mathrm{J}-11$ and $\mathrm{J}-12$ are listed in table 1, and are described in the individual well sections.

Water-level altitudes in this report are based on a survey of selected water-level monitoring network reference points in 1993 by the U.S. Geological Survey.

\section{Precision and Accuracy}

An analysis of precision and accuracy was conducted for manual water-level measurements, which includes all periodic measurements, obtained during 1988-90 (Boucher, 1994). The precision of the 2,800-ft reference steel tape, based on 31 measurements, was $0.026 \mathrm{ft}$. The precision of Chain \#2, based on 341 measurements, was $0.014 \mathrm{ft}$. The precision of Chain \#1 has not been calculated, but is considered consistent with the precision of Chain \#2. Ninetyseven percent of all measurements obtained with the steel tapes (not including Chain \#1) were precise to within $0.05 \mathrm{ft}$ during 1988-90.

The accuracy of the computed water-level altitude is a function of the accuracy of the: (1) Waterlevel measurement, (2) borehole correction, (3) height of the measuring point, (4) altitude of the reference point, and (5) the precision of the $2,800-\mathrm{ft}$ reference steel tape. Accuracy of the borehole-correction factors is unavailable because borehole-deviation surveys have not been run in wells $\mathrm{J}-11$ and $\mathrm{J}-12$. The unknown accuracy of the borehole corrections poses a problem in the calculation of overall accuracy values. The overall accuracy of measurements taken with the steel tapes is estimated to be $0.36 \mathrm{ft}$, neglecting the accuracy of the borehole-correction factor (Boucher, 1994).

\section{Quality Assurance}

Data in this report will be used to evaluate the suitability of the Yucca Mountain site for a high-level nuclear-waste repository. Confidence in the reliability of water-level data is necessary so the data may be used with confidence to assess the expected performance of the repository. A quality-assurance program has been implemented to support the reliability of the data.

\section{On-Site Procedures}

The quality-assurance program requires that water-level measurements be obtained by methods described in formal technical procedures. The techni- 
cal procedures include tests and adjustments done during the measuring operation to ensure that the equipment is operating properly and that expected precision and accuracy are attained. For example, the procedure for measuring water-level with a steel tape specifies how to use the tape, when to calibrate it against the reference steel tape, and how to maintain the records of the calibrations.

Data are recorded in logbooks in the field. Data recorded include: Time and date of the visit; names of operators making the visit; identification of specific equipment used; and correction factors, if any, applied to the data at the well site. In addition, the entry in the logbooks may include comments concerning factors that may be relevant to the collected data, such as discussion of problems with equipment or weather conditions during the water-level measurement.

\section{Office Processing and Review}

The original logbooks and records are maintained throughout a calendar year at the onsite operations headquarters at the Nevada Test Site. Photocopies are periodically transmitted to the office of the project chief in Denver, Colo. The records are reviewed for completeness and accuracy, and to ensure that proper technical procedures were followed. Any needed adjustments not done during on-site operations are made in the Denver office. At the end of the calendar year, after data reviews have been conducted and any needed adjustments have been made, the original logbooks and related records are transferred to a Yucca Mountain Project data archive in Denver.

\section{WELL DATA AND WATER LEVELS}

Information and data for wells $\mathrm{J}-11$ and $\mathrm{J}-12$ are included in the following sections. References or information sources, well specifications, periodic water-level measurement data, and hydrographs of water-level altitude are presented for each well. The well specifications include location, land-surface altitude, start and completion dates of drilling, drilling method, depth drilled, bit diameter below water level, casing extending below water level, description of access tubes for measuring water levels, description and altitude of reference point, and description and height of MP above reference point. Mean-annual water-level altitudes for 1989-91 are calculated.

\section{Well J-11}

1. References or information sources: Young, R.A., 1972; Fenix \& Scisson, Inc. 1987.

2. Well specifications:

a. Location:

Nevada State Central Zone Coordinates (m):

N 740,968; E 611,764.

Latitude and longitude: $36^{\circ} 47^{\prime} 06^{\prime \prime} \mathrm{N}$.;

$116^{\circ} 17^{\prime} 06^{\prime \prime} \mathrm{W}$.

Site ID: 364706116170601.

b. Land-surface altitude: $1,049.45 \mathrm{~m}$ (surveyed by U.S. Geological Survey, 1993).

c. Date drilling started: June 4, 1957.

d. Date drilling completed: July 19, 1957.

e. Drilling method: Cable-tool.

f. Total drilled depth: $405 \mathrm{~m}$.

g. Bit diameter below water level: $400 \mathrm{~mm}$

h. Casing extending below water level: 308-mm inside-diameter casing extends from land surface to $404.5 \mathrm{~m}$.

i. Description of access for measuring water levels, including tubes or piezometers: $308-\mathrm{mm}$ insidediameter casing; the casing is perforated from 328.3 to $334.4 \mathrm{~m}$ and from 379.2 to $396.2 \mathrm{~m}$. The well produces water from the basalt of Kiwi Mesa and from the welded-tuff aquifer, located within the Topopah Spring Member of the Paintbrush Tuff.

j. Description and altitude of reference point: Chiseled " $\mathrm{X}$ " in concrete pad near well, altitude $1,049.45 \mathrm{~m}$ (surveyed by U.S. Geological Survey, 1993).

k. Description and height of MP above reference point: Top of casing, even with top of concrete block, $0.55 \mathrm{~m}$ above the reference point.

3. Water-level altitudes:

Mean water-level altitude for 1989-91 at well J-11 was $732.19 \mathrm{~m}$. The mean altitude was $732.17 \mathrm{~m}$ for $1989,732.21 \mathrm{~m}$ for 1990 , and $732.20 \mathrm{~m}$ for 1991 . Water-level altitudes ranged from 732.09 to $732.40 \mathrm{~m}$ during 1989-91. Water-level altitudes are listed in table 3 and shown in figure 2 . 
Table 3. Measured water-level altitude and yearly mean water-level altitudes, 1989-91, for well J-11 near Yucca Mountain, Nevada

[Method: C1, Chain \#1; C2, Chain \#2; R, reference steel tape]

\begin{tabular}{|c|c|c|}
\hline Date & $\begin{array}{l}\text { Water-level altitude } \\
\text { (meters) }\end{array}$ & Method \\
\hline $01 / 30 / 89$ & 732.17 & $\mathrm{C2}$ \\
\hline $06 / 12 / 89$ & 732.18 & $\mathrm{C} 2$ \\
\hline $12 / 08 / 89$ & 732.16 & $\mathrm{C} 2$ \\
\hline $02 / 12 / 90$ & 732.25 & $\mathrm{C} 2$ \\
\hline $07 / 10 / 90$ & 732.14 & $\mathrm{C} 2$ \\
\hline $07 / 20 / 90$ & 732.20 & $\mathrm{C} 2$ \\
\hline $07 / 27 / 90$ & 732.16 & $\mathrm{C} 2$ \\
\hline $07 / 31 / 90$ & 732.19 & $\mathrm{C} 2$ \\
\hline $08 / 09 / 90$ & 732.17 & $\mathrm{C} 2$ \\
\hline $08 / 15 / 90$ & 732.22 & $\mathrm{C} 2$ \\
\hline $08 / 21 / 90$ & 732.17 & $\mathrm{C} 2$ \\
\hline $08 / 27 / 90$ & 732.15 & $\mathrm{C} 2$ \\
\hline $09 / 14 / 90$ & 732.21 & $\mathrm{C} 2$ \\
\hline $10 / 19 / 90$ & 732.25 & $\mathrm{C} 2$ \\
\hline $11 / 19 / 90$ & 732.31 & $\mathrm{C} 2$ \\
\hline $12 / 13 / 90$ & 732.29 & $\mathrm{C} 2$ \\
\hline 01/24/91 & 732.23 & $\mathrm{C} 2$ \\
\hline $02 / 28 / 91$ & 732.40 & $\mathrm{C} 2$ \\
\hline $03 / 27 / 91$ & 732.23 & $\mathrm{C} 1$ \\
\hline $04 / 19 / 91$ & 732.19 & $\mathrm{C} 1$ \\
\hline $05 / 07 / 91$ & 732.18 & $\mathrm{C} 1$ \\
\hline $06 / 10 / 91$ & 732.17 & $\mathrm{C} 1$ \\
\hline $07 / 23 / 91$ & 732.18 & $\mathrm{C} 1$ \\
\hline $08 / 22 / 91$ & 732.18 & $\mathrm{C} 1$ \\
\hline $09 / 16 / 91$ & 732.14 & $\mathrm{Cl}$ \\
\hline $10 / 31 / 91$ & 732.09 & $\mathrm{Cl}$ \\
\hline $11 / 26 / 91$ & 732.21 & $\mathrm{Cl}$ \\
\hline $12 / 16 / 91$ & 732.17 & $\mathbf{R}$ \\
\hline 1989 mean: & $732.17 \mathrm{~m}$ & \\
\hline 1990 mean: & $732.21 \mathrm{~m}$ & \\
\hline 1991 mean: & $732.20 \mathrm{~m}$ & \\
\hline 1989-91 mean: & $732.19 \mathrm{~m}$ & \\
\hline
\end{tabular}

\section{Well J-12}

1. References or information sources: Young, R.A., 1972; Fenix \& Scisson, Inc. 1987.
2. Well specifications:

a. Location: Nevada State Central Zone Coordinates (m): N 733,508; E 581,012

Latitude and longitude: $36^{\circ} 45^{\prime} 54^{\prime \prime} \mathrm{N}$.; $116^{\circ} 23 ' 24^{\prime \prime} \mathrm{W}$.

Site ID: 364554116232401

b. Land-surface altitude: $953.54 \mathrm{~m}$ (survey by U.S.Geological Survey, 1993).

c. Date drilling started: August 4, 1957.

d. Date drilling completed: October 9, 1957; well was deepened in August 1968.

e. Drilling method: Cable-tool (1957); unknown 1968.

f. Total drilled depth: $271 \mathrm{~m}$ (1957); $347 \mathrm{~m}$ after the deepening in 1968.

g. Bit diameter below water level: $400-\mathrm{mm}$ to $271 \mathrm{~m}, 298-\mathrm{mm}$ to $347 \mathrm{~m}$.

h. Casing extending below water level: $308-\mathrm{mm}$ inside-diameter casing extending from land surface to $271 \mathrm{~m}$.

i. Description of access for measuring water levels, including tubes or piezometers: $308-\mathrm{mm}$ insidediameter casing; the casing is perforated between 241-264 m; the hole is open from $271 \mathrm{~m}$ to $347 \mathrm{~m}$; access tube is $54-\mathrm{mm}$ outside-diameter. The well produces water from the welded-tuff aquifer, located within the Topopah Spring Member of the Paintbrush Tuff.

j. Description and altitude of reference point: Top of well collar, $954.54 \mathrm{~m}$ (surveyed by U.S. Geological Survey, 1993).

k. Description and height of MP above reference point: Top of the 54-mm outside-diameter access tube, $0.53 \mathrm{~m}$ above the reference point.

3. Water-level altitudes:

Mean water-level altitude for 1989-91 at well J-12 was $727.95 \mathrm{~m}$. The mean altitude was $727.95 \mathrm{~m}$ for $1989,727.94 \mathrm{~m}$ for 1990 , and $727.95 \mathrm{~m}$ for 1991 . Water-level altitudes ranged from 727.84 to $728.03 \mathrm{~m}$ during 1989-91. Water-level altitudes are listed in table 4 and shown in figure 3 . 


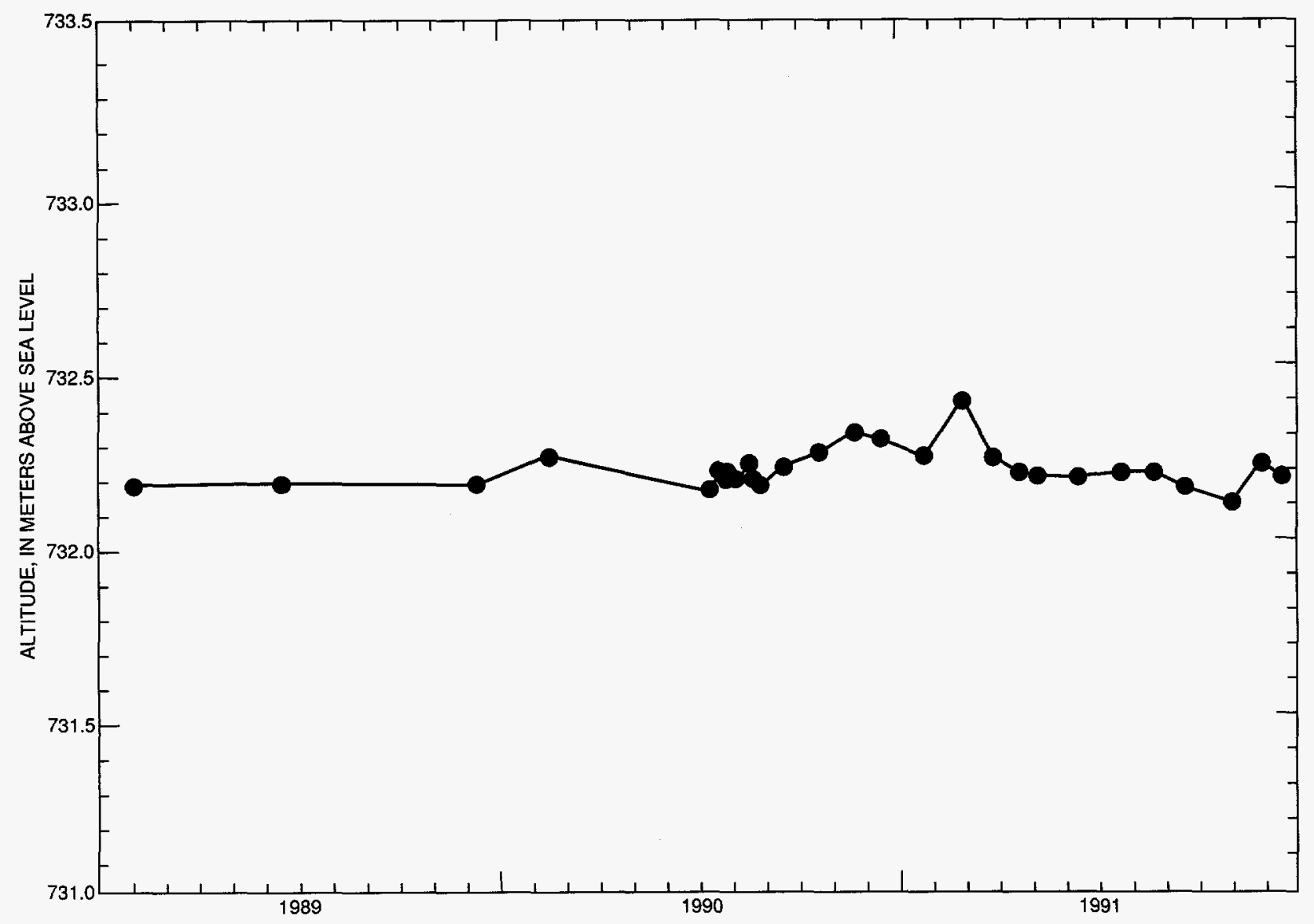

Figure 2. Water-level altitude, 1989-91, for well J-11 near Yucca Mountain, Nevada. 
Table 4. Measured water-level altitude and yearly mean water-level altitudes, 1989-91, for well $\mathrm{J}-12$ near Yucca Mountain, Nevada

[Method: C1, Chain \#1; C2, Chain \#2; R, reference steel tape]

\begin{tabular}{ccc}
\hline Date & $\begin{array}{c}\text { Water-level altitude } \\
\text { (meters) }\end{array}$ & Method \\
\hline $08 / 28 / 89$ & 728.00 & $\mathrm{C} 2$ \\
$10 / 02 / 89$ & 728.03 & $\mathrm{C} 2$ \\
$11 / 16 / 89$ & 727.94 & $\mathrm{C} 2$ \\
$12 / 22 / 89$ & 727.84 & $\mathrm{C} 2$ \\
$01 / 25 / 90$ & 727.89 & $\mathrm{C} 2$ \\
$02 / 08 / 90$ & 727.91 & $\mathrm{C} 2$ \\
$03 / 09 / 90$ & 727.99 & $\mathrm{C} 2$ \\
$04 / 17 / 90$ & 727.98 & $\mathrm{C} 2$ \\
$05 / 30 / 90$ & 727.95 & $\mathrm{C} 2$ \\
$06 / 18 / 90$ & 727.89 & $\mathrm{C} 2$ \\
$07 / 10 / 90$ & 727.90 & $\mathrm{C} 2$ \\
$08 / 20 / 90$ & 727.94 & $\mathrm{C} 2$ \\
$09 / 14 / 90$ & 727.94 & $\mathrm{C} 2$ \\
$10 / 29 / 90$ & 727.98 & $\mathrm{C} 2$ \\
$11 / 27 / 90$ & 727.90 & $\mathrm{C} 2$ \\
\hline
\end{tabular}

Table 4. Measured water-level altitude and yearly mean water-level altitudes, 1989-91, for well J-12 near Yucca Mountain, Nevada --Continued

[Method: C1, Chain \#1; C2, Chain \#2; R, reference steel tape]

\begin{tabular}{ccc}
\hline Date & $\begin{array}{c}\text { Water-level altitude } \\
\text { (meters) }\end{array}$ & Method \\
\hline $12 / 13 / 90$ & 727.99 & $\mathrm{C} 2$ \\
& & \\
$02 / 25 / 91$ & 727.88 & $\mathrm{C} 2$ \\
$04 / 24 / 91$ & 727.94 & $\mathrm{C} 1$ \\
$05 / 14 / 91$ & 727.96 & $\mathrm{C} 1$ \\
$06 / 10 / 91$ & 727.94 & $\mathrm{C} 1$ \\
$07 / 23 / 91$ & 727.92 & $\mathrm{C} 1$ \\
$08 / 21 / 91$ & 727.93 & $\mathrm{C} 1$ \\
$09 / 12 / 91$ & 727.94 & $\mathrm{C} 1$ \\
$10 / 25 / 91$ & 727.97 & $\mathrm{C} 1$ \\
$11 / 21 / 91$ & 727.98 & $\mathrm{C} 1$ \\
$12 / 17 / 91$ & 728.01 & $\mathrm{R}$ \\
\hline 1989 mean: & $727.95 \mathrm{~m}$ & \\
1990 mean: & $727.94 \mathrm{~m}$ & \\
1991 mean: & $727.95 \mathrm{~m}$ & \\
$1989-91$ mean: & $727.95 \mathrm{~m}$ & \\
\hline
\end{tabular}

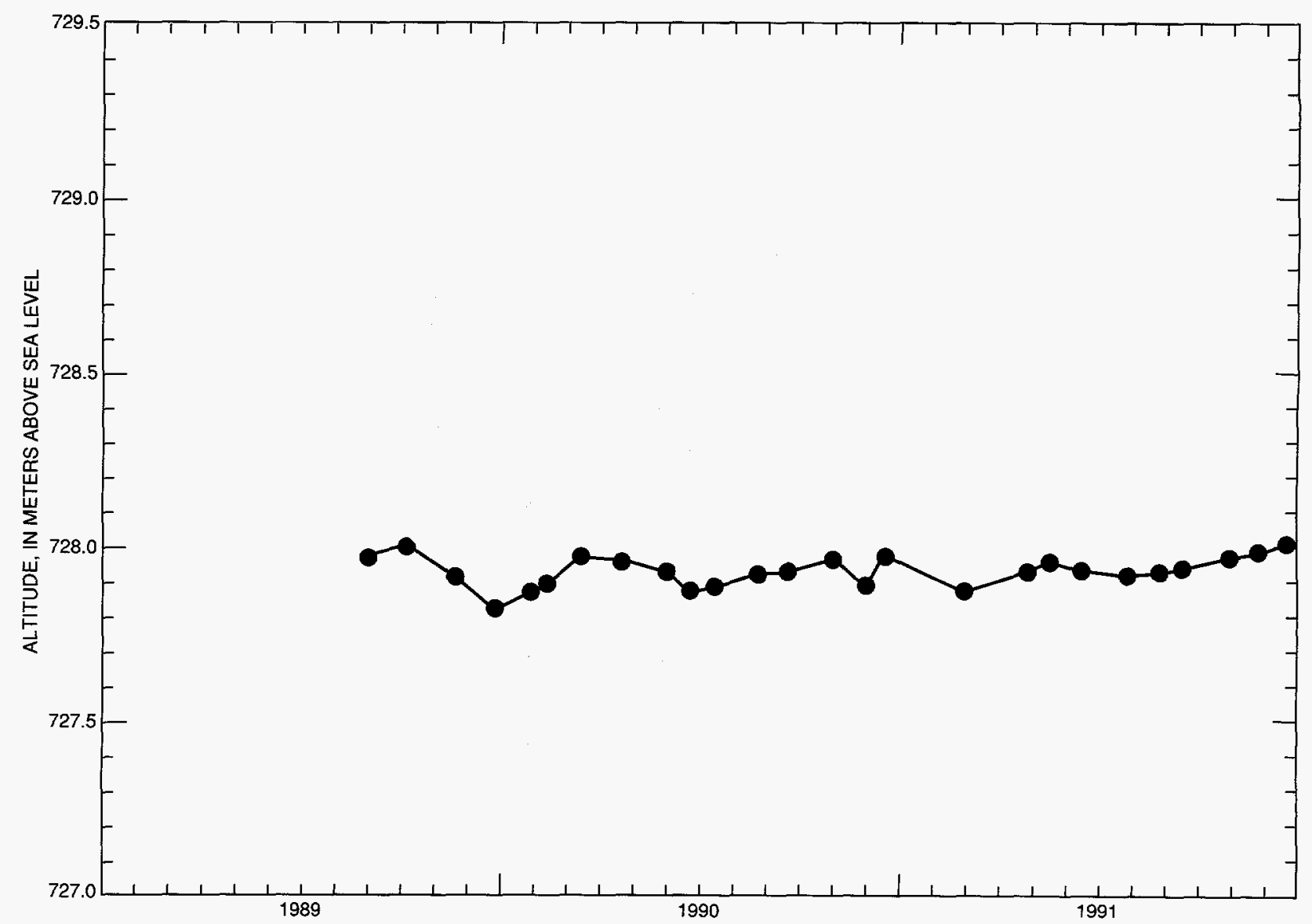

Figure 3. Water-level altitude, 1989-91, for well J-12 near Yucca Mountain, Nevada. 


\section{REFERENCES CITED}

Boucher, M.S., 1994, Precision and accuracy of manual water-level measurements taken in the Yucca Mountain area, Nye County, Nevada, 1988-90: U.S. Geological Survey Water-Resources Investigations Report 93-4025, 18 p. (NNA.930323.0149)

Byers, F.M., Jr., Carr, W.J., Orkild, P.P., Quinlivan, W.D., and Sargent, K.A., 1976, Volcanic suites and related cauldrons of Timber Mountain-Oasis Valley caldera complex, southern Nevada: U.S. Geological Survey Professional Paper 919, 70 p. (NNA.870406.0239)

Carr, W.J., Byers, F.M., Jr., and Orkild, P.P., 1986, Stratigraphic and volcano-tectonic relations of Crater Flat Tuff and some older volcanic units, Nye County, Nevada: U.S. Geological Survey Professional Paper 1323, 28 p. (HQS.880517.1115)

Carr, W.J., 1988, Volcano-tectonic setting of Yucca Mountain and Crater Flat, southwestern Nevada, in Carr, M.D. and Yount, J.C. (eds.), Geologic and hydrologic investigations of a potential nuclear waste disposal site at Yucca Mountain, southern Nevada: U.S. Geological Survey Bulletin 1790, p. 35-49. (NN1.881128.0011)

Fenix \& Scisson, Inc., 1987, NNWSI drilling and mining summary: U.S. Department of Energy DOE/NV/ $10322-24,45$ p. (NNA.890922.0283)

Gemmell, J.M., 1990, Water levels in periodically measured wells in the Yucca Mountain area, Nevada, 1988:
U.S. Geological Survey Open-File Report 90-113, 47 p. (NNA.900221.0001)

O'Brien, G.M., 1991, Water levels in periodically measured wells in the Yucca Mountain area, Nevada, 1989: U.S. Geological Survey Open-File Report 91-178, 51 p. (NNA.910708.0041)

Robison, J.H., Stephens, D.M., Luckey, R.R., and Baldwin, D.A., 1988, Water levels in periodically measured wells in the Yucca Mountain area, Nevada, 1981-87: U.S. Geological Survey Open-File Report 88-468, 132 p. (NNA.890306.0113)

Sass, J.H., and Lachenbruch, A.H., 1982, Preliminary interpretation of thermal data from the Nevada Test Site: U.S. Geological Survey Open-File Report 82-973,30p. (HQS.880517.1427)

U.S. Department of Energy, 1988, Site characterization plan, Yucca Mountain site, Nevada research and development area, Nevada: U.S. Department of Energy Report DOE RW/0199, 8v., various pagination. (HQS.881201)

Winograd, I.J., and Thordarson, William, 1975, Hydrogeologic and hydrochemical framework, south-central Great Basin, Nevada-California, with special reference to the Nevada Test Site: U.S. Geological Survey Professional Paper 712-C, 126 p. (HQS.880517.2908)

Young, R.A., 1972, Water supply for the Nuclear Rocket Development Station at the U.S. Atomic Energy Commission's Nevada Test Site: U.S. Geological Survey Water-Supply Paper 1938, 19 p. (NNA.870519.0007) 